\title{
Photos stop as Landsat 7 defies engineers
}

Tony Reichhardt, Washington

Engineers are struggling to fix a problem with the Landsat 7 remote-sensing satellite that has left global-change researchers without their primary source of new large-scale images of the Earth.

Project managers for the US Geological Survey, who manage the satellite from NASA's Goddard Space Flight Center in Maryland, have yet to fully understand the situation. The fault, which first occurred late last month, lies with the Scan Line Corrector, a device that compensates for Landsat's motion and stops pictures becoming blurred. Without it, about $25 \%$ of each image is severely degraded.

Bruce Quirk, the Geological Survey's chief scientist for remote-sensing systems, says it may take two more weeks to find out whether the failure is electrical or mechanical. An electrical fault would be preferable, as the satellite carries back-up electrical systems.

But engineers could find new ways of creating useable images if the failure is mechanical, adds Quirk. Data near the centre of each image are less affected, and it should be possible to provide equivalent coverage by combining multiple images of a ground target - although the process would increase the time needed to create undistorted scenes.

Regular photography has been suspended, a blow to the remote-sensing researchers who used it. The satellite and its predecessors, each government-run, have been taking the same kind of image for 31 years, allowing users to track changes over time. Landsat 7 normally collects 250 large-scale images, of $183 \times 170$ kilometres each, every day.

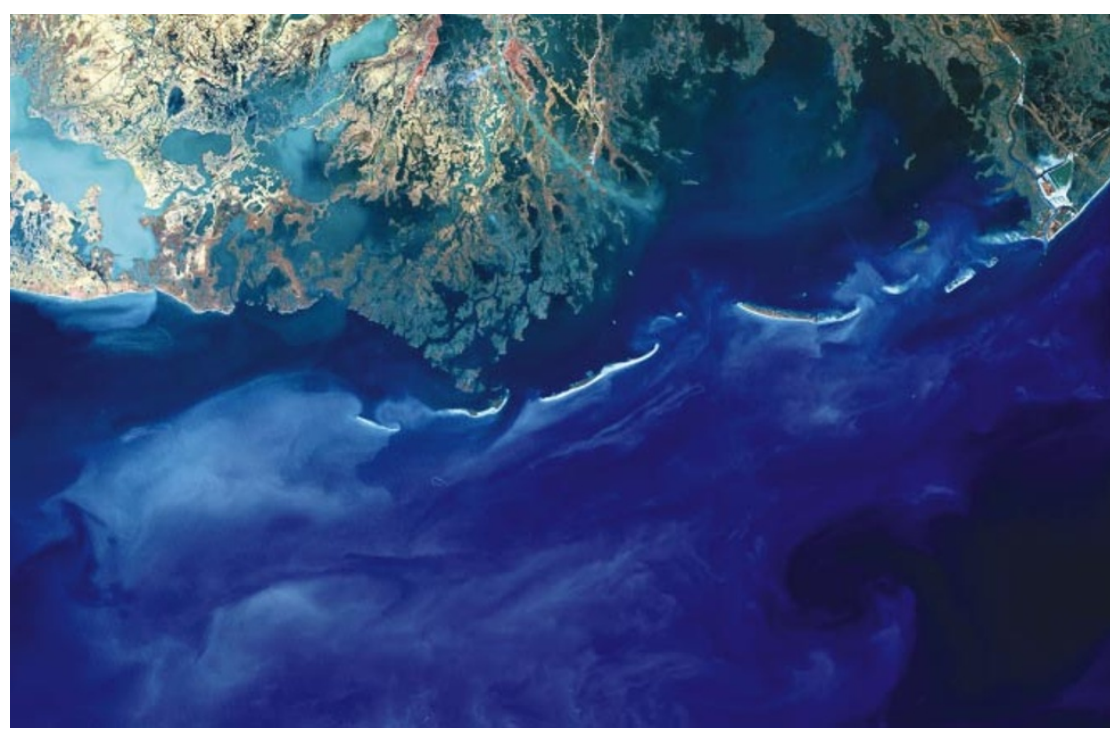

Picture this: researchers rely on Landsat's images, such as this one of silt in the Gulf of Mexico.

The problem comes just as Landsat's privatization is being considered. Congress and the Bush administration would like to see the next satellite owned and run by the private sector, which would sell the data to scientists and other users (see Nature 419, 328; 2002).

But one of two companies expected to bid for the contract - DigitalGlobe of Longmont, Colorado - withdrew earlier this year, saying the venture was too risky commercially. The government insists on keeping image prices low enough for researchers to afford, and the market - mainly federally funded scientists - is not large.

That left Resource 21 of Denver, Colorado, as the only company known to be in the running. NASA officials won't say whether they have received other bids, but the contract award, planned for this month, has been delayed, probably until late summer.

Thomas Lillesand, director of the Environmental Remote Sensing Center at the University of Wisconsin at Madison, says that trying to increase Landsat usage is a chicken-and-egg problem. The market for images should be growing as new imageanalysis tools become available, but users won't commit themselves unless "we can get sufficient numbers of satellites up there that we can depend on".

\section{Dolly firm in trouble after transgenic milk fails to flow}

Jenny Hogan, London

The company that helped create Dolly may follow the cloned sheep to an early grave.

PPL Therapeutics announced on 18 June that its leading project, an attempt to harvest therapeutic proteins from the milk of transgenic sheep, was being put on hold. About half of the Edinburgh-based firm's 200 employees will lose their jobs, and the company itself could fold, some analysts say.

When PPL was established in 1989, the company hoped to clone flocks of genetically modified sheep and cows, and milk them for therapeutic proteins - and for money. But the firm has been forced to sell off several transgenic projects in the past few years. Its share price, which exceeded $\mathfrak{E} 4$ (US\$6.68) in the mid-1990s, is now about 6 pence.

The latest setback concerns plans to develop a protein treatment for lung diseases such as hereditary emphysema and cystic fibrosis in partnership with Bayer, a US pharmaceutical company. PPL had developed transgenic sheep that expressed the protein $\alpha_{1}$-antitrypsin in their milk, and was preparing to collaborate with Bayer to run large-scale human trials of the treatment.

Bayer say they have now placed the trials on hold after PPL decided not to take on the $\mathfrak{E} 42$ million of debt required to finance the building of a commercial-scale plant for purifying the protein from the milk.

"Without a production facility, you can do all the clinical trials in the world and there still won't be a drug at the end of it," says Tricia McKernan, who is director of communications for Bayer Biological Products at Research Triangle Park in North Carolina.
PPL now faces a difficult future. It has only one product that looks likely to become profitable - another protein called fibrin, a surgical 'glue' that can replace stitches and which is not derived using transgenic techniques. But the market for this is crowded, says Julie Simmonds, a biotech analyst at Evolution Beeson Gregory in London. "We remain unconvinced about the long-term outlook for PPL," she adds.

The business has already been heavily pruned. PPL sold its xenotransplantation arm this April, and closed down its stem-cell projects last September.

Geoff Cook, PPL's chief executive, says that the decision about what to do next lies with shareholders, and warns that they may decide that selling the company's remaining assets is the best way to recoup their investment. 